\title{
The development of export oriented agriculture: methods of region export potential assessment
}

\author{
Valentina Kundius and Irina Kovaleva \\ Altai State Agrarian University, 656049, Barnaul, Altai Territory, Russia
}

\begin{abstract}
The study uses a systematic approach to ensure the complexity and focus of scientific recommendations, analytical, abstract-logical, calculating-constructive, economic-statistical, economic-mathematical, monographic methods of research. The methodical approach to justifying the placement of organic agricultural products and food production, localizing it using method of mapping. The Based on the acceptance of mapping with allocation locally segments based on certain criteria or features based on the points-rating system.

This allows us to distinguish local segments of industry production and organic farming using signs of geographical and behavioral segmentation. At the same time, the criterion of segmentation by geographical basis may be the natural and economic zoning of the area in question; the criterion of segmentation by behavioral basis may be the degree of need of the residents of the area for a particular product. In the end, the allocation of segments is reduced to ranking local zones of production and processing of organic agricultural products and markets, forming in them
\end{abstract}

\section{Literary review and research methods}

Based on theoretical and methodological research - the work of domestic and foreign scientists on the development of organic agricultural production; Land development; research and recommendations of the Russian Academy of Agricultural Sciences, laws, presidential decrees and executive orders of the Government of the Russian Federation, regulations of the subjects of the Russian Federation, EU regulations on the development of environmental agriculture, IFOAM standards.

The study uses a systematic approach to ensure the complexity and focus of scientific recommendations, analytical, abstract-logical, calculating-constructive, economicstatistical, economic-mathematical, monographic methods of research. The methodical approach to justifying the placement of organic agricultural products and food production, localizing it using method of mapping. The Based on the acceptance of mapping with allocation locally segments based on certain criteria or features based on the points-rating system.

This allows us to distinguish local segments of industry production and organic farming using signs of geographical and behavioral segmentation. At the same time, the criterion of segmentation by geographical basis may be the natural and economic zoning of the area in question; the criterion of segmentation by behavioral basis may be the degree of need of the residents of the area for a particular product. In the end, the allocation of segments is 
reduced to ranking local zones of production and processing of organic agricultural products and markets, forming in them

\section{The results and discussion}

The intensification of competition in industrial commodity markets dictates the need to study their condition with the identification of development trends and prospects. Crop production sectors are traditionally strategic in the Russian Federation, including in terms of expanding export supplies of agricultural raw materials and food. Steady growth in export supplies of grain crops and sunflower oil brought Russia to second place in the world (Fig. 1)

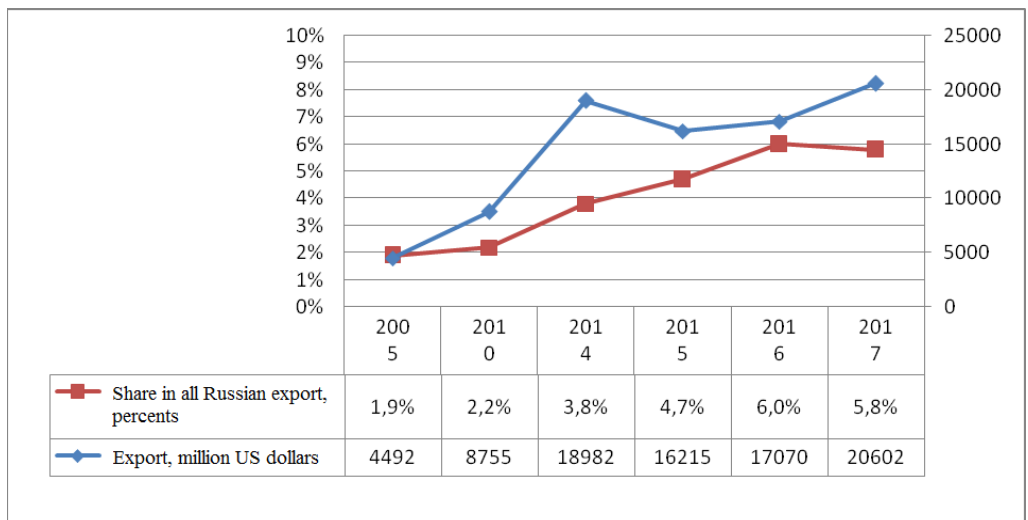

Fig.1. Dynamics of export supplies of agricultural products and food in Russia $[1,2,3]$.

The development of crop industries involves technical re-equipment of the industry. The analysis shows the negative dynamics of decrease in the level of technical equipment of the industry, which is explained by a number of reasons with the predominance of economic factors (Fig. 2)

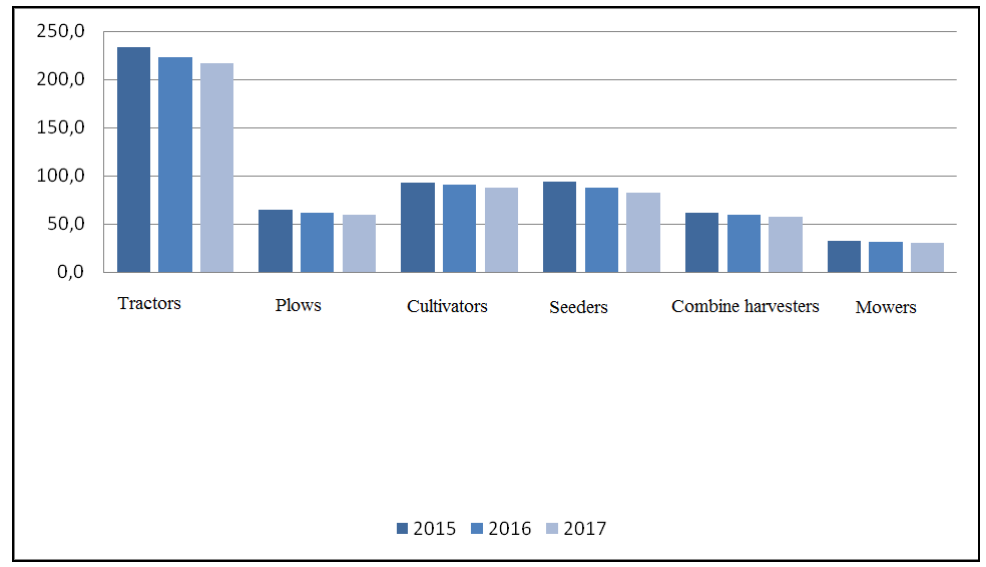

Fig. 2. Trends in the technical equipment of the park in agricultural organizations, RF, thousand units $[1,2,3]$. 
In the Altai Krai, despite positive changes in the level of equipment with fixed assets, the problem of modernization and re-equipment remains relevant (Fig. 3)

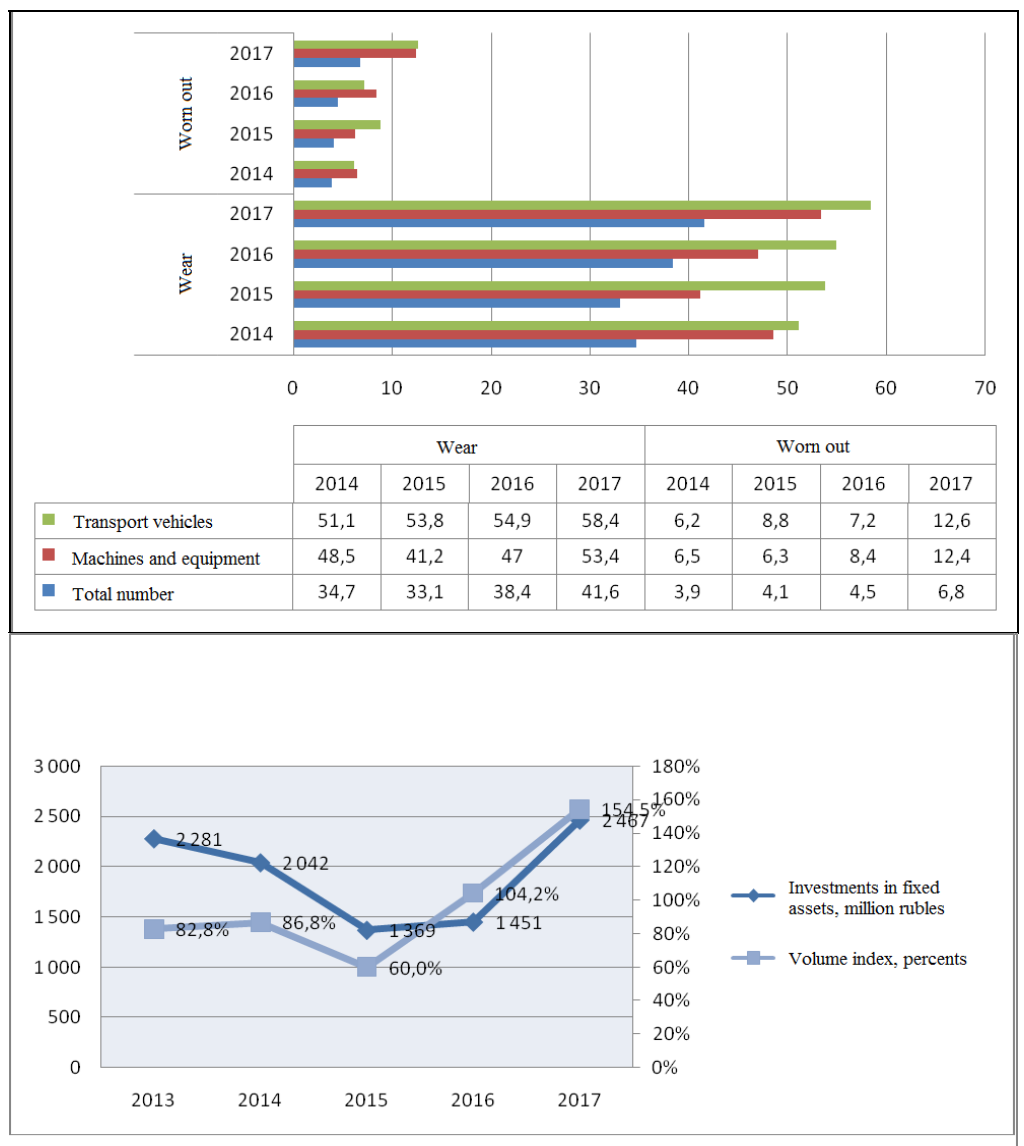

Fig. 3. The level of depreciation and investment of fixed assets of agricultural organizations $[4,5]$.

The impact of the industry's development on the environment is increasing: thus, emissions and discharges of pollutants into water and air basins have increased by 1.7 times, which is faster than the dynamics of gross grain and vegetable harvest. Waste generation increased by 3.4 times. When the share of agriculture in the gross water intake increases to $25 \%$, it accounts for more than $60 \%$ of water losses during transportation (Table 1) [6].

Table 1. Dynamics of the industry's environmental impact $[1,2,6]$.

\begin{tabular}{|l|c|c|c|c|c|c|}
\hline Indicators & 2005 & 2010 & 2014 & 2015 & 2016 & Gain \\
\hline $\begin{array}{l}\text { Share in water withdrawal from natural } \\
\text { sources, percent }\end{array}$ & 13,9 & 22,2 & 23,8 & 23,0 & 25,3 & $\begin{array}{c}1,8 \\
\text { times }\end{array}$ \\
\hline $\begin{array}{l}\text { Discharge of polluted wastewater into surface } \\
\text { water bodies, mln m }\end{array}$ & 470,0 & 380,0 & 783,0 & 771,9 & 816,8 & $\begin{array}{c}1,7 \\
\text { times }\end{array}$ \\
\hline $\begin{array}{l}\text { Emissions of air polluting substances from } \\
\text { stationary sources, thousand tons }\end{array}$ & 134,1 & 136,6 & 185,3 & 197,3 & 218,2 & $\begin{array}{c}1,7 \\
\text { times }\end{array}$ \\
\hline
\end{tabular}




\begin{tabular}{|l|c|c|c|c|c|c|}
\hline Wastegeneration, milliontons & 14,3 & 24,0 & 43,1 & 45,8 & 49,2 & $\begin{array}{c}3,4 \\
\text { times }\end{array}$ \\
\hline
\end{tabular}

In the Altai Krai, in recent years, there has been a tendency for the cultivation of industrial crops, one of which is rapeseed.

Rapeseed is a unique crop in terms of nutritional content and green yield.

Table 2. Gross harvest of industrial crops in the Altai Krai [7].

\begin{tabular}{|c|c|c|c|c|c|c|c|c|}
\hline & \multicolumn{2}{|c|}{2015} & \multicolumn{2}{|c|}{2016} & \multicolumn{2}{|c|}{2017} & \multicolumn{2}{|c|}{2018 . } \\
\hline $\begin{array}{l}\text { The name of } \\
\text { the crop }\end{array}$ & $\begin{array}{c}\text { thousan } \\
\text { dtons }\end{array}$ & $\%$ & $\begin{array}{c}\text { thousan } \\
\text { dtons }\end{array}$ & $\%$ & $\begin{array}{c}\text { thousan } \\
\text { dtons }\end{array}$ & $\%$ & $\begin{array}{c}\text { thousan } \\
\text { dtons }\end{array}$ & $\%$ \\
\hline $\begin{array}{l}\text { linenflax- } \\
\text { seeds }\end{array}$ & 0,26 & 0,01 & 0,31 & 0,01 & 0,02 & 0,00 & 0,20 & 0,01 \\
\hline $\begin{array}{l}\text { linenflax- } \\
\text { straw }\end{array}$ & 17,35 & 0,94 & 18,20 & 0,70 & 13,44 & 0,48 & 12,00 & 0,39 \\
\hline $\begin{array}{l}\text { linenflax- } \\
\text { flax-fibre }\end{array}$ & 4,57 & 0,25 & 4,75 & 0,18 & 4,10 & 0,15 & 3,67 & 0,12 \\
\hline sugarbeet & 819,63 & 44,62 & 1131,13 & 43,32 & 1084,61 & 38,89 & 888,11 & 28,67 \\
\hline $\begin{array}{l}\text { oil crops - } \\
\text { total }\end{array}$ & 498,50 & 27,14 & 729,59 & 27,94 & 845,24 & 30,30 & 1098,51 & 35,46 \\
\hline $\begin{array}{l}\text { sunflowerfo } \\
\text { rgrain }\end{array}$ & 386,44 & 21,04 & 568,98 & 21,79 & 619,72 & 22,22 & 676,41 & 21,84 \\
\hline $\begin{array}{l}\text { Crownflax } \\
\text { (oil) }\end{array}$ & 41,20 & 2,24 & 53,12 & 2,03 & 44,96 & 1,61 & 78,72 & 2,54 \\
\hline soybean & 27,88 & 1,52 & 55,67 & 2,13 & 97,97 & 3,51 & 135,77 & 4,38 \\
\hline mustard & 0,05 & 0,00 & 0,00 & 0,00 & 0,73 & 0,03 & 3,54 & 0,11 \\
\hline $\begin{array}{l}\text { springrape - } \\
\text { colza }\end{array}$ & 41,06 & 2,24 & 49,07 & 1,88 & 78,31 & 2,81 & 200,88 & 6,48 \\
\hline $\begin{array}{l}\text { Totalindust- } \\
\text { rialcrops }\end{array}$ & 1836,95 & 100,00 & 2610,82 & 100,00 & 2789,11 & 100,00 & 3097,80 & 100,00 \\
\hline
\end{tabular}

The cultivation of rapeseed in the Altai Krai is carried out by agricultural organizations of all categories. In the structure of gross rapeseed collection by organizations, there was an increase in rapeseed collection by peasant (farmer) enterprises and individual entrepreneurs by $2.6 \%$ compared to 2015 . Thus, interest in the cultivation of spring rape by peasant (farmer) farms increased. (Table 3).

Table 3. Gross harvest of spring rape in the Altai Krai [7].

\begin{tabular}{|l|c|c|c|c|c|c|c|c|}
\hline \multirow{2}{*}{ Indicators } & \multicolumn{2}{|c|}{2015} & \multicolumn{2}{c|}{2016} & \multicolumn{2}{c|}{2017} & \multicolumn{2}{c|}{2018} \\
\cline { 2 - 9 } & $\begin{array}{l}\text { thousa } \\
\text { ndtons }\end{array}$ & $\%$ & $\begin{array}{c}\text { thousan } \\
\text { dtons }\end{array}$ & $\%$ & $\begin{array}{c}\text { thousan } \\
\text { dtons }\end{array}$ & $\%$ & $\begin{array}{c}\text { thousan } \\
\text { dtons }\end{array}$ & $\%$ \\
\hline $\begin{array}{l}\text { Farmsofall- } \\
\text { categories }\end{array}$ & 41,06 & 100 & 49,07 & 100 & 78,31 & 100,00 & 200,88 & 100,00 \\
\hline $\begin{array}{l}\text { Agricultural- } \\
\text { organizations }\end{array}$ & 32,18 & 78,37 & 35,69 & 72,73 & 59,93 & 76,53 & 152,2 & 75,77 \\
\hline $\begin{array}{l}\text { Peasant (farm) } \\
\text { enterprises and } \\
\text { individual } \\
\text { entrepreneurs }\end{array}$ & 8,88 & 21,63 & 13,38 & 27,27 & 18,38 & 23,47 & 48,68 & 24,23 \\
\hline
\end{tabular}


The market of rapeseed producers in the Altai Krai is represented by agricultural organizations. Households do not grow rapeseed. Over the analyzed period, a decrease in the share of rapeseed production by agricultural organizations by $2.6 \%$ occurred. This is due to an increase in the share of gross rapeseed in the total harvestingby peasant (farmer) farms and individual entrepreneurs.

Table 4. The balance of rapeseed in the Altai Krai, thousand tons [6,7].

\begin{tabular}{|l|c|c|c|c|}
\hline \multicolumn{1}{|c|}{ Indicators } & 2015 & 2016 & 2017 & 2018 \\
\hline Production & 36,5 & 43,4 & 71,4 & 184,3 \\
\hline Import & 26,8 & 33,6 & 30,7 & 38,0 \\
\hline Carry-over balance & 3,1 & 0,5 & 2,1 & 54,3 \\
\hline Domesticconsumption & 65,6 & 67,1 & 59,3 & 72,9 \\
\hline Taking out & 0,9 & 9,4 & 44,9 & 95,1 \\
\hline Including export & 0,9 & 9,4 & 44,9 & 95,1 \\
\hline
\end{tabular}

Another popular crop is potato (35.8\% of all-Russian production). The Altai Krai ranks sixth in its cultivation (production of 992.2 thousand tons per year), which is $3.13 \%$ of the Federal level. At the same time, it is necessary to take into account the global trend of growing potatoes in small businesses and private households [8]. Study of the region's export potential shows promising directions for the development of export-oriented agriculture and the processing of these products in order to strengthen export positions in agri-food markets in the Altai Krai [9]. The natural climatic and resource potential of the region makes it possible to grow rye, barley, buckwheat, soybeans, flax, which are in demand on world markets, and to produce organic products with the Altai Product brand, which has established itself in the markets as environmentally friendly products with high taste and health-friendly properties. In general, in the dynamics of exports, its growth has been observed in recent years (Table 5).

Table 5. Export supplies in the region.

\begin{tabular}{|l|c|c|r|r|r|r|r|r|}
\hline & \multicolumn{2}{|c|}{2015} & \multicolumn{2}{c|}{2016} & \multicolumn{2}{c|}{2017} & \multicolumn{2}{c|}{2018} \\
\cline { 2 - 9 } & Mln\$ & $\begin{array}{c}\text { growth } \\
\text { rate 2014, } \\
\%\end{array}$ & Mln\$ & $\begin{array}{c}\text { growth } \\
\text { rate } \\
2015, \%\end{array}$ & Mln\$ & $\begin{array}{c}\text { growth } \\
\text { rate } \\
2016, \%\end{array}$ & Mln\$ & $\begin{array}{c}\text { growth } \\
\text { rate } \\
2017, \%\end{array}$ \\
\hline Total export & 428,9 & 95,1 & 665,3 & 100,3 & 948 & 142,5 & 1135 & 119,2 \\
\hline $\begin{array}{l}\text { Export } \\
\text { ofagriculture }\end{array}$ & 146,8 & 99,1 & 183,7 & 125,1 & 185,8 & 101,1 & 198,4 & 106,8 \\
\hline \multicolumn{2}{|r|}{ Source: [11] } & \multicolumn{7}{|c|}{} \\
\hline
\end{tabular}

The regions of the Russian Federation are distinguished by specific economic, natural, and demographic conditions, which complicates the development of a single, unified approach to export regional policy. In this regard, both universal indicators for assessing their export potential and specific ones are needed. It is proposed to conduct a multifactorial assessment of the export potential of the region, depending on the specifics of its socioeconomic and natural-climatic conditions.

The group of common indicators that make it possible to assess the export potential includes: the effectiveness and efficiency of foreign economic activity, such absolute indicators as the volume of agricultural production by type, gross regional product; volumes of export, import, foreign trade turnover and foreign trade balance.

The group of relative indicators for assessing the dynamics and level of foreign economic activity of a region includes the following: first of all, the growth rates of export, 
import, and foreign trade turnover, which make it possible to assess how the volumes of export, import, or overall foreign trade will increase in the study period, as compared to the base period, or, in the case of its reduction, what proportion it will be from the base level. An important indicator of foreign economic and export activity is considered to be "openness of the region's economy" [12, p.111]. The degree of general openness of the economy will characterize the ratio of the commodity exchange volume (inter-regional and foreign economic) to the gross regional product (GRP) produced. It is possible to assess the openness of the economy by individual sectors and product groups based on the use of special factors binding export, import, production and domestic consumption.

The export rate (coefficient of marketability of regional production) is calculated by the formula:

$$
\mathrm{K}_{\mathrm{v}}=\mathrm{v} / \mathrm{q},
$$

where $\mathrm{v}$ - the export of products,

$q$ - the volume of production.

The import coefficient (the share of import to the total consumption of products in the region) is calculated by the formula:

$$
\mathrm{K}_{\mathrm{w}}=\mathrm{w} / \mathrm{q}-\mathrm{v}+\mathrm{w}
$$

where $\mathrm{w}$ - the import of products.

Exchange rate:

$$
\mathrm{K} \mathrm{v}+\mathrm{w}=\mathrm{v}+\mathrm{w} / \mathrm{q}
$$

These coefficients allow to diagnose objectively the degree of development of foreign economic (export) activities of the region and competently build or adjust the strategy of regional export development.

Rastvortseva S.N. and Kolchinskaya E.E. analyze the export potential of the region on the basis of a methodology consisting of such stages as:

1) determination of the inclusion degree of the region in the international division of labor;

2) analysis of the industrial capabilities of the region as promising areas of export;

3) assessment of the level of development of transport infrastructure, including the availability of transport hubs;

4) analysis of institutional factors of foreign economic activity of the region $[13,16]$.

Vasyutchenko I.N. offers to study the export potential of the agricultural sector of the region on the basis of a system of indicators by the following factors: natural resource potential, production potential, human potential, organizational and managerial potential, innovative potential, marketing potential, investment potential [13]. In this connection integral indicator of the region's export capabilitiescan be calculated [14, p. 16].

$$
R E P=\sum_{i=1}^{7} R E P_{i} \cdot v_{i},
$$

where $\sum_{i=1}^{7} v_{i}=1$, where $R E P$ is the i-th component of the region's export potential;

$\mathrm{V}_{\mathrm{i}}$ - weight of the i-th component of the region's export potential. In its turn, the ЭП $\mathrm{P}_{\mathrm{i}}$ is defined as follows:

$$
R E P_{i}=\sum_{j=1}^{n} g_{i j} \cdot p_{j},
$$

where $\sum_{j=1}^{n} p_{j}=1$, where $\mathrm{p}_{\mathrm{j}}$ is the weight of the $\mathrm{j}^{\text {th }}$ indicator; $\mathrm{g}_{\mathrm{ij}}-$ component of the region's export potential; $\mathrm{n}$ is the number of indicators forming one of the components of the region's export potential.

S.Yu. Perunov, A.S. Ilyinskaya believe that, based on the definition, the export potential of the region can be defined by the sum of its main components, to which it relates: 
- exported goods produced in the region, but sold by supra-regional organizations-state corporations;

- transit rent charged for the transit of export goods through the region;

- goods produced in the region, partially or fully exported on behalf of the region;

- export of services at the regional level $[15,16]$.

Therefore, the common indicator, which will fully calculate the export potential of the region, will be as follows:

$$
\mathrm{P}_{\mathrm{com}}=\sum_{i=1}^{4} P_{i}
$$

Where $\mathrm{P}_{1}$ - export of goods produced in the region, but sold by supra-regional organizations; $\mathrm{P}_{2}$ - transit rent charged for the transit of export goods across the region; $\mathrm{P}_{3}$ export of goods produced in the region, partially or fully sold on behalf of the region; $\mathrm{P}_{4}$ export of regional services.

\section{Conclusion}

Given the growing trends in demand for natural organic agricultural products and food in the domestic and international markets, the Altai Krai has great advantages and opportunities for the development of export potential in this direction. The Federal project "Export of agricultural products" is being implemented in the region, in accordance with which it is planned to increase food exports from Altai by almost three times. However, the region's export development is affected by a number of constraining factors, including such as high logistic costs, protective fees and quotas of potential trade partners of the Altai Krai, difficulties with product certification, and the presence of stable trading partners abroad.In this regard, both organizational and financial support is required, as well as export stimulation by the state, which will allow developing exports and increasing the competitiveness of Altai products on world markets. After analyzing the general situation on the regional market of Altai agro-industrial complex, the dynamics of export of the agroindustrial complex of the region, the measures taken by the state support, as well as the problems faced by local exporters, we made a number of recommendations on increasing the export of agricultural and food products of Altai producers.

These recommendations take into account global trends in the development of agricultural production. First of all, this is an increase in the production of organic and bioproducts for export, as well as the production of bio-fuels and raw materials for its production, processing of agricultural products and sales mainly to the countries of Southeast Asia.

\section{Acknowledgments}

The research was conducted and the article was published with the financial support of the RFFI under a grant for the implementation of the scientific project No. 19-510-44011 Mong_t "Development of the concept of organic agriculture development based on progressive methods and technologies" 


\section{References}

1. Agricultural products in 2017, the Federal State Statistics Service, http://www.gks.ru/free_doc/doc_2016/bul_dr/sx/sxprod2016.xls

2. Regions of Russia, Socio-economic indicators, 2017 http://www.gks.ru/bgd/regl/b17_14p/Main.htm

$\begin{array}{llll}3 . & \text { Regions of Russia, Socio-economic indicators, } 2018\end{array}$ http://www.gks.ru/free doc/doc 2018/region/soc-pok.rar

4. Investing in agriculture, URL: https://kudainvestiruem.ru/kuda-vlozhit/investicii-vselskoe-hozyajstvo.html

5. The nature, types and sources of investment in agriculture, URL: https://vikidalka.ru/478974.html

6. Data of the Federal State Statistics Service, URL: https: //showdata.gks.ru/report/277040/

7. The sown area of spring rape Altai Territory, URL: https: //selkhozportal.rf/analizposevnyh-ploshhadej/? Region_id $=2198 \&$ area $=9$

8. A.Walter, R. Finger, R. Huber, N. Buchmann, Proceedings of the National Academy of Sciences of the United States of America, 114 (24), 6148-6150 (2017)

9. V.A. Kundius, O.Yu. Voronkova, A.V. Ivanov, A.V. Glotko, D. G. Galkin, I.A. Svistula Prospects for the production of environmentally friendly products in the transboundary territories of Greater, 204 (Altai: monograph, Barnaul, AZBUKA, 2016)

10. V. A. Kundius, Export potential of agriculture in Russia's regions. - Proceedings of the XXI International scientific and practical conference, Nikon readings, 378 (2020)

11. A. A. Nikonovviapi, Export potential of the Russian agro-industrial complex, Encyclopedia of Russian villages, 215-219 (Moscow, 2016)

12. Statistical information on the results of foreign trade of the Altai Territory, URL: http://stu.customs.ru/index.php?option=com_content\&view $=$ category\&id=177\&Itemid $=252$. (appeal date: 07/11/2019)

13. A. G. Granberg, Fundamentals of the regional economy, 4th ed. - 495 (M.: Publishing. house of the Higher School of Economics, 2004)

14. S. N. Rastvortseva, E. E. Kolchinskaya, Scientific reports of Belgorod State University, Series: Economics, Computer science, 22-1 (165) (2013) URL: https://cyberleninka.ru/article/n/vneshneekonomicheskaya-deyatelnost-kak-faktorrazvitiya-rossiyskih-regionov

15. I.N. Vasyutchenko, Inertial diversification of agricultural exports in the regions of the South of Russia: institutional aspect, 27 (Rostov-on-Don, 2012)

16. S. Yu. Perunov, Formation and development of the export potential of the region (on the example of the Rostov region, 148 (Rostov-on-Don, 2015)

17. A. S. Ilinskaya, Export potential of the agro-industrial complex of the region (on the example of the Altai territory), 117 (Barnaul, 2019) 